\title{
IMPACT OF LOCAL INFILTRATION ANESTHESIA ON POSTOPERATIVE PAIN MANAGEMENT AFTER RHINOPLASTY IN DAY CARE SURGERY
}

\author{
Tomica Bagatin ${ }^{1,5}$, Dinko Bagatin ${ }^{2,5}$, Livija Šakić ${ }^{4}$ and Kata Šakić3,4,6
}

\begin{abstract}
${ }^{1}$ Department of Maxillofacial, Plastic, Reconstuctive and Aesthetic Surgery at Maxillofacial, General, Plastic, Reconstructive and Aesthetic Surgery Polyclinic "Bagatin”, Zagreb, Croatia; ${ }^{2}$ Department of General, Plastic, Reconstuctive and Aesthetic Surgery at Maxillofacial, General, Plastic, Reconstructive and Aesthetic Surgery Polyclinic "Bagatin", Zagreb, Croatia; ${ }^{3}$ Department of Anaesthesiology and Pain therapy at Maxillofacial, General, Plastic, Reconstructive and Aesthetic Surgery Polyclinic "Bagatin", Zagreb, Croatia; ${ }^{4}$ Department of Anaesthesiology, Reanimathology and Intensive medicine University hospital "Sveti Duh", Zagreb, Croatia; ${ }^{5}$ Faculty of Dental medicine and Health Osijek, Josip Juraj Strossmayer University in Osijek, Osijek, Croatia; ${ }^{6}$ Catholic University of Croatia, Zagreb, Croatia
\end{abstract}

SUMMARY - Use of local infiltration anaesthesia with $2 \%$ lidocaine in combination with epinephrine $1 / 100000$ in rhinoplasty and $0.25 \%$ levobupivacaine in this research as an adjunct to general anaesthesia is compared analysing the need for postoperative analgesia in rhinoplasty patients. 30 patients received lidocaine combined with epinephrine (LA) and other 30 patients received levobupivacaine (LB). Comparison is done with Visual Analogue Scale in 30 min and 1, 3, $6 \mathrm{~h}$ postoperatively. Also $24 \mathrm{~h}$ need for analgesic treatment was recorded. In conclusion postoperative analgesia in LB group with general anaesthesia was significantly prolonged $(\mathrm{P}=0.038)$.

Key words: local infiltration anaesthesia, lidocaine, levobupivacaine, day care surgery, rbinoplasty, pain management

\section{Introduction}

Rhinoplasty is a surgical procedure that corrects different nasal deformities and is one of the most challenging procedures in facial aesthetic surgery. It is performed in general anaesthesia and usually certain regions of the nose are infiltrated with epinephrine for vasoconstriction and bleeding reduction of the surgical field $^{1,2}$. Lidocaine was the first local anaesthetic administered with epinephrine for the same reasons ${ }^{1}$.

Combination of general and local infiltration anaesthesia before first incision reduces postoperative analgesia requirements after rhinoplasty procedure ${ }^{3}$.

Correspondence to: Tomica Bagatin, MD, Department of Maxillofacial, Plastic, Reconstuctive and Aesthetic Surgery at Maxillofacial, General, Plastic, Reconstructive and Aesthetic Surgery Polyclinic "Bagatin", Zagreb, Croatia

Email: tomica.bagatin@bagatin.hr
This synergistic effect reduces complications and enhances postoperative recovery ${ }^{4}$.

A small number of studies in scientific literature compare the influence of different local anaesthetics and other adjuvants for postoperative analgesia after rhinoplasty procedure.

In this study, we compared preincisional administration of $2 \%$ lidocaine with epinephrine and $0.25 \%$ of levobupivacaine for postoperative analgesia in patients who underwent nasal surgery.

\section{Methods}

The study was conducted in "Bagatin" Polyclinic, a private facility polyclinic for maxillofacial and plastic surgery. Sixty patients were enrolled in this prospective, randomised, clinical trial, American Society of Anes- 


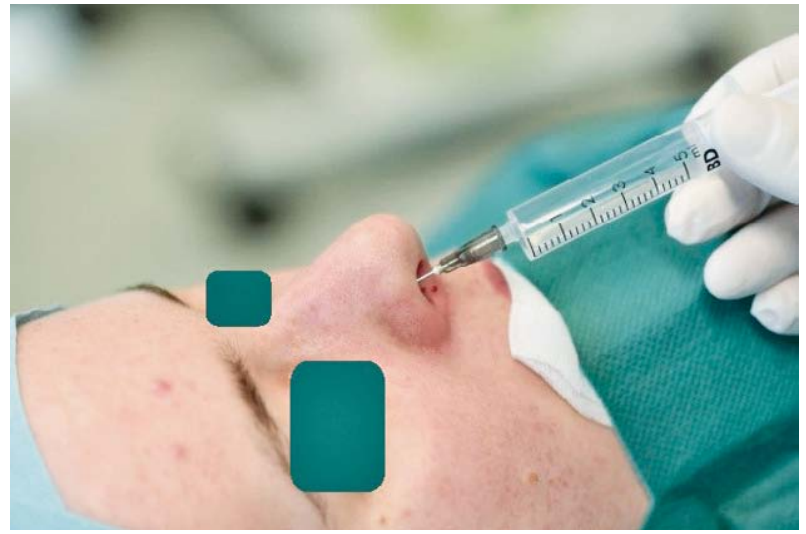

Fig. 1. Preincisional nose infiltration of levobupivacaine before rbinoseptoplasty surgical procedure.

thesiologists (ASA) physical status 1 and 2. Patients were male and female and underwent nasal surgery procedure. Patients were randomly assigned to receive preincisional local infiltration in general anaesthesia. Thirty patients received infiltration of lidocaine $2 \%$ in combination with epinephrine 1:100000 in the surgical field, the LA group, while other thirty patients received infiltration of 6 millilitres $(\mathrm{ml})$ of $0.25 \%$ of levobupivacaine in the surgical field before the first surgical cut.

Table 1. Correlation of age with the rhinoplasty procedure: chi $i^{2}$ test

\begin{tabular}{|l|l|l|l|}
\hline & \multicolumn{2}{|l|}{ Age } & \multirow{2}{*}{$\mathrm{P}^{*}$} \\
\cline { 2 - 4 } & $20-39$ years & $\geq 40$ & \\
\hline rhinoplasty group & $38(63.3)$ & $22(36.7)$ & $<\mathbf{0 . 0 0 1}$ \\
\hline
\end{tabular}

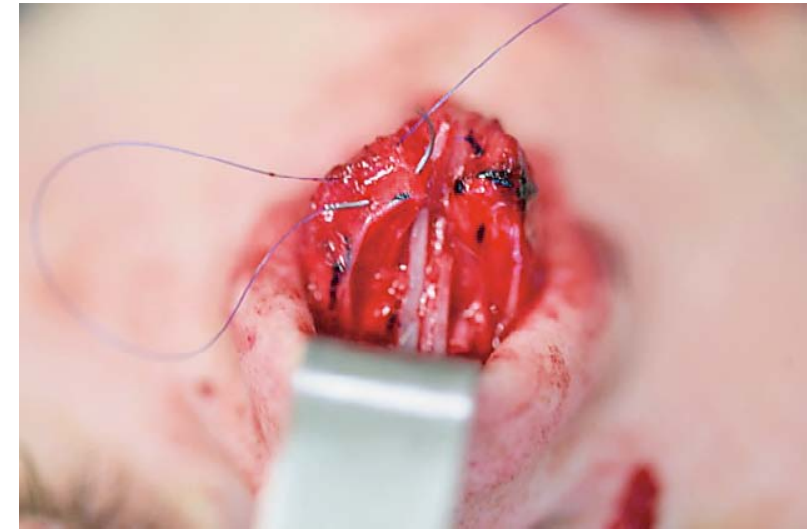

Fig. 2. Infiltrated surgical field during rbinoseptoplasty procedure.

A 30-gauge short needles and 25-gauge long needles were used for the infiltration of the anaesthetic agent in surgical dissection planes.

Infiltration sequence:

1. Septum infiltration is submucoperichondrial resulting in a hydraulic dissection for reconstruction or graft harvesting.

2. Dorsum is infiltrated along the lateral part of upper lateral cartilages and nasal bones in supraperichondral and supraperiosteal plane. Infiltration is done in anterograde and retrograde fashion. Care is taken not to infiltrate in wrong plane and not to infiltrate too much fluid (more than $2 \mathrm{ml}$ ).

3. In lateral wall infiltration we start at pyriform aperture and then proceed to the lateral part of the frontal process of maxilla for lateral osteotomies,

Table 2. Characteristics of anaesthesia techniques and comparison of postoperative pain level

\begin{tabular}{|c|c|c|c|}
\hline & \multicolumn{2}{|c|}{$\begin{array}{l}\text { Group of } 60 \text { patients, ASA 1,2 } \\
\mathrm{f} / \mathrm{m} 44 / 16 \text {, average } 26(20-41) \text { yrs }\end{array}$} \\
\hline & & $\begin{array}{l}30 \text { patients LB } \\
\text { Rhinoseptoplasty in General } \\
\text { Anesthesia with LIA } \\
\text { Levobupivacaine } 0.25 \%\end{array}$ & $\begin{array}{l}30 \text { patients LA } \\
\text { Rhinoseptoplasty } \\
\text { in General Anesthesia } \\
\text { with LIA Lidocaine } 2 \%\end{array}$ \\
\hline \multicolumn{2}{|c|}{ Volumen of preload $(0.9 \% \mathrm{NaCl}-\mathrm{ml})$} & 500 & 500 \\
\hline \multirow{2}{*}{$\begin{array}{l}\text { Local Infiltration } \\
\text { Analgesia drug dose }\end{array}$} & $\begin{array}{l}\text { Levobupivacaine } 0.25 \% \text { Lidocaine } \\
2 \%+0.075 \mathrm{mg} \text { Adrenaline } 1:\end{array}$ & $15.00 \mathrm{mg}$ & $120 \mathrm{mg}$ \\
\hline & Total analgesia (minutes) & $232(186-258)$ & $56(42-115)$ \\
\hline \multicolumn{2}{|c|}{ Postoperative VAS; 30 min (mean, min-max) } & 0 & 0 \\
\hline \multicolumn{2}{|c|}{ Postoperative VAS; 1 h (mean, min-max) } & $0(0-2)$ & $3(1-4)$ \\
\hline \multicolumn{2}{|c|}{ Postoperative VAS; 3 h (mean, min-max) } & $0.5(0-2)$ & $4(1-6)$ \\
\hline \multicolumn{2}{|c|}{ Postoperative VAS; 6 h (mean, min-max) } & $1(0-2)$ & $3(1-5)$ \\
\hline
\end{tabular}


on the junction of the frontal process of maxilla and nasal bones for intermediate and further up for the medial osteotomies. Infiltration is performed in anterograde and retrograde fashion in supraperiosteal plane.

4. Columella is infiltrated in subcutaneous plane starting at the anterior nasal spine of maxilla up the medial crura of the lower lateral cartilages to the domes and in front of medial crura et domes. Deposition takes place during anterograde deposition and withdrawal of the needle.

5. Tip infiltration is marginal incision; in external approach it includes multiple deposits of the local anaesthetic solution that are placed along the caudal edge of the lateral crus extending to the anterior side.

6. Alar base is infiltrated into the alar lobule, leaving a small deposit without disturbing the original contour (Fig. 1, Fig. 2)

Visual Analogue Scale (VAS) was performed for evaluating postoperative pain intensity.

VAS scores were assessed 30 minutes (min) after surgery and 1, 3 and 6 hours (h) postoperatively. The rescue analgesic requirements in 24 hour postoperative period were noted as well.

The statistics data are shown in tables and figures. The data for descriptive variables were analysed by chisquare test, differences in quantitative variables were tested by Mann-Whitney $U$ test and Fisher exact test. Statistical analysis was performed by the IBM SPSS Statistics for Windows 23.

\section{Results}

Pain intensity assessed by VAS scores 30 min after surgery was significantly lower in the group that received levobupivacaine with statistically significant $P$ value, $\mathrm{P}<0.0001$.

Pain intensity assessed 1 hour after surgery, $\mathrm{P}=$ $0.002,3$ hours postoperatively, $\mathrm{P}=0.023$, and 6 hours after surgery $\mathrm{P}<0.0001$, were lower in the LB group in comparison to the LA group as well.

Total analgesic requirement was significantly lower in group that received levobupivacaine when compared to the parallel group $(\mathrm{P}=0.038)$.

Conventional nonsteroidal anti-inflammatory drugs in combination with paracetamol, administered in time to provide sufficient analgesia, but weak opioids are recommended for moderate pain, and strong opioids for severe pain, on request.

This has been the reason patients have been more active immediately in postoperative period and their discharge was on the day of the surgical treatment.

\section{Discussion}

Different types of anaesthesia are administered in rhinoplasty. Infiltration block combining lidocaine with ketamine solution during rhinoplasty decreased pain and postoperative analgesic consumption during first $24 \mathrm{~h}$ after the operation ${ }^{5}$. Articaine as a local infiltration anaesthetic administered for septoplasty procedure in comparison to lidocaine showed rapid onset of action $^{6}$. General anaesthesia combining remifentanil and desflurane in combination with extraoral infratrohlear and infraorbital nerve blocks reduce perioperative morphine dose, time spent in the post-anaesthesia care unit and the outpatient ward in adult patients undergoing rhinoseptoplasty ${ }^{7}$. Granier et al. used intranasal lidocaine plus naphazoline and proved it as a simple and efficient technique for decreasing intra- and postoperative pain and for lessening rescue analgesic requirements in the postoperative period after rhinoseptoplasty ${ }^{8}$. Toxic plasma concentrations of lidocaine were not reached after performing intravenous anaesthesia and when compared to local anaesthesia and with lidocaine in rhinoplasty procedures ${ }^{9}$. Levobupivacaine was confirmed to be effective for obtaining postoperative analgesia following septoplasty procedure with local anaesthesia and when compared to lidocaine, it increases the postoperative comfort of the patients by reducing pain levels after septoplasty procedures ${ }^{10}$. In our study analgesic requirements were significantly lower in the group that received levobupivacaine when compared to the group that received most frequently used lidocaine with epinephrine. Local anaesthetics in cosmetic head and neck surgery show an increasing trend. The use of sedation technique and dissociative anaesthesia in combination with local anaesthesia has both proved to be safe and effective anaesthetic methods for performing rhinoplasty $^{11}$.

This study has confirmed local infiltration of levobupivacaine preincisionally is significantly more potent and longer lasting than that achieved by lidocaine 
plus epinephrine. No more than $6 \mathrm{ml}$ solution of 0.25 $\%$ of levobupivacaine is needed for complete analgesia and vasoconstriction. A 30-gauge short needles and 25-gauge long needles are enough for the infiltration of the anaesthetic agent in surgical dissection planes. Distortion of the nose caused by improper deposition and an overdose of local anaesthetic should be prevented.

Nonsteroidal anti-inflammatory drugs in combination with paracetamol are sufficient analgesia in the early recovery phase. Weak opioids are recommended for moderate pain, and strong opioids for severe pain ${ }^{12}$. Rescue analgesics requirements assessed in the first 24 hours were reduced in the group that received preincisional LIA.

\section{Conclusion}

Local infiltration of levobupivacaine before incision in general anaesthesia significantly prolonged postoperative analgesia in comparison to combination of lidocaine with epinephrine. In early recovery phase, sufficient analgesia was provided with nonsteroidal anti-inflammatory drugs (NSAIDs) with paracetamol. In cases of moderate pain weak opioids were administered and in severe pain cases strong opioids were the medications of choice.

\section{Acknowledgements}

The authors thank the Medical Staff of Polyclinic "Bagatin" and the students (Farah Al-Khazae, Matea Sarka, Ema Šaić and Marijana Grden) of Faculty of Dental Medicine and Health Osijek for their support and assistance.

\section{References}

1. Goktas U, Isik D, Kati I, Atik B, Soyoral L. Effects of lidocaine infiltration on cost of rhinoplasty made under general anesthesia. J Craniofac Surg. 2011;22(6):2176-8. https://doi.org/10.1097/SCS.0b013e318232414c.
2. Al-Moraissi EA, Ellis E. Local versus general anesthesia for the management of nasal bone fractures: a systematic review and meta-analysis. J Oral Maxillofac Surg. 2015 Apr;73(4): 606-15. https://doi.org/10.1016/j.joms.2014.10.013

3. Demiraran Y, Ozturk O, Guclu E, Iskender A, Ergin MH, Tokmak A. Vasoconstriction and analgesic efficacy of locally infiltrated levobupivacaine for nasal surgery. Anesth Analg. 2008;106(3):1008-11. htpps://doi.org/10.1213/ane.0b013e31816174c3

4. Koeppe T, Constantinescu MA, Schneider J, Gubisch W. Current trends in local anesthesia in cosmetic plastic surgery of the head and neck: results of a German national survey and observations on the use of ropivacaine. Plast Reconstr Surg. 2005; 115(6):1723-30.

5. Şanli M, Gülhaş N, Bilen BT, Erdoğan Kayhan G, Uçar M, et al. The effect of addition of ketamine to lidocaine on postoperative pain in rhinoplasties. Turk J Med Sci. 2016;19;46(3): 789-94. https://doi.org/10.3906/sag-1409-101

6. Erkul E, Babayigit M, Kuduban O. Comparison of local anesthesia with articaine and lidocaine in septoplasty procedure. Am J Rhinol Allergy. 2010, 24(5):e123-6. https://doi.org/10.1097/EJA.0b013e32833a45c4

7. Boselli E, Bouvet L, Augris-Mathieu C, Bégou G, Diot-Junique N, Rahali N, et al. Infraorbital and infratrochlear nerve blocks combined with general anaesthesia for outpatient rhinoseptoplasty: A prospective randomised, double-blind, placebocontrolled study. Anaesth Crit Care Pain Med. 2016 ;35(1): 31-36. https://doi.org/10.1016/j.accpm.2015.09.002

8. Granier M, Dadure C, Bringuier S, Bonnet-Boyer MC, Ryckwaert $\mathrm{Y}$, Loriaux $\mathrm{E}$, et al. Intranasal lidocaine plus naphazoline nitrate improves surgical conditions and perioperative analgesia in septorhinoplasty surgery. Can J Anaesth. 2009;56(2): 102-8. htpps://doi.org/10.1007/s12630-008-9020-7

9. Sklar M, Golant J, Solomon P. Rhinoplasty with intravenous and local anesthesia. Clin Plast Surg. 2013;40(4):627-9. htpps: //doi.org/10.1016/j.cps.2013.08.002

10. Yilmaz YF, Ozlugedik S, Titiz A, Tuncay A, Ozcan M, Unal A. Comparison of levo-bupivacaine and lidocaine for postoperative analgesia following septoplasty. Rhinology. 2008;46(4): 289-91.

11. Courtney MJ, Rajapakse Y, Duncan G, Morrissey G. Nasal fracture manipulation: a comparative study of general and local anaesthesia techniques. Clin Otolaryngol Allied Sci. 2003;28 (5):472-5. https://doi.org/10.1111/j.1365-2273.2004.00942.x

12. Rawal N. Current issues in postoperative pain management. Eur J Anaesthesiol. 2016;33:160-71. https://doi.org/10.1097/ EJA.0000000000000366 


\title{
Sazetak
}

\section{UČINAK LOKALNE INFILTRACIJSKE ANESTEZIJE NA LIJEČENJE POSLIJEOPERACIJSKE BOLI KOD RINOPLASTIKE U DNEVNOJ KIRURGIJE}

\author{
T. Bagatin, D. Bagatin, L. Šakić i K. Šakić
}

Preoperativnu lokalnu infiltracijsku anesteziju sa $2 \%$ lidokainom u kombinaciji sa epinefrinom 1/100000 i 0,25 \% levobupivakainom kao dodatku općoj anesteziji uspoređivali smo mjerenjem potrebe za postoperativnom analgezijom u pacijenata koji su se podvrgli operativnom zahvatu korekcije nosa. 30 pacijenata je primilo lidokain u kombinaciji sa epinefrinom (LA), a drugih 30 pacijenata je primilo levobupivakain (LB). PremaVisualnoj analgnoj skali s (VAS) mjerena je razina boli nakon 30 min, 1, 3, 6 sati. Isto tako unutar 24 sata mjerena je potreba za analgetskom terapijom. Poslijeoperacijska analgezija je trajala značajno dulje u skupini pacijenata LB u kojoj je primijenjen levobupivakain u kombinaciji sa općom anestezijom $(\mathrm{P}=0.038)$.

Ključne riječi: lokalna infiltracijska anestezija, lidokain, levobupivakain, ambulantna kirurgija, rinoplastika, kontrola boli 